\title{
Sexually Transmitted Disease: Shadow on the Land Revisited
}

\section{Citation}

Allan M. Brandt. 1990. Sexually transmitted disease: Shadow on the land revisited. Annals of Internal Medicine 112(7): 481-483.

\section{Published Version}

http://www.annals.org/content/vol112/issue7/

\section{Permanent link}

http://nrs.harvard.edu/urn-3:HUL.InstRepos:3372903

\section{Terms of Use}

This article was downloaded from Harvard University's DASH repository, and is made available under the terms and conditions applicable to Other Posted Material, as set forth at http:// nrs.harvard.edu/urn-3:HUL.InstRepos:dash.current.terms-of-use\#LAA

\section{Share Your Story}

The Harvard community has made this article openly available.

Please share how this access benefits you. Submit a story.

\section{Accessibility}




\title{
Annals of Internal Medicine
}

\author{
E D I T OR I A L
}

\section{Sexually Transmitted Disease: Shadow on the Land, Revisited}

Since Surgeon General Thomas Parran (1) began his campaign in the 1930 s to wipe out syphilis-"the shadow on the land"-partner notification has been considered an important element of public health policy to control epidemic disease. Case finding through notification of partners was based on the common-sense notion that early intervention among persons who were often unaware that they might be infected could lead to the control of diseases like syphilis. Parran called for a "Wassermann dragnet": vigorous screening, reporting, contact tracing, and treatment to rid the nation of the scourge of sexually transmitted disease. When first proposed and implemented in the 1930s and 1940 s, partner notification for sexually transmitted diseases held great promise. Typically, public health officers reported on field investigations where epidemics, traced back to a single index patient, were "shut down" through dogged "shoe leather epidemiology." No doubt, Parran's program met with considerable success, breaking the conspiracy of silence associated with these diseases and attracting much needed attention and resources (2).

Unfortunately, the specific aspects of these programs have rarely been systematically evaluated to examine their efficacy as public health policies. Partner notification programs, for example, have typically been debated on ideologic grounds: Does the State have a right to require reporting and aggressively trace sexual contacts or is such activity a violation of basic rights of privacy and confidentiality? On a pragmatic level, does the knowledge that infected individuals will be questioned about their sexual contacts discourage persons from seeking appropriate care? Although supporters of the programs typically cite the number of new cases discovered through notification (3), detractors typically cite the fact that discovered cases may only represent a small proportion of actual new infections (4). Do partner notification programs achieve their goals? It is striking how little is known about the relative cost and effectiveness of these programs.

In this issue, Andrus and colleagues (5) report the results of an evaluation of the effectiveness of partner notification in controlling epidemic syphilis. The casecontrol study conducted in Oregon in 1987 is impor- tant because it is one of the rare instances in which a longstanding public health program has been subjected to careful and rigorous assessment. The paper shows that the "technologies" of public health can be subjected to scientific evaluation. How well do the available tools meet the demands of a particular epidemic? To mandate such interventions without previous assessment of their efficacy, as well as their costs and benefits, could lead to the substantial commitment of limited resources (both human and financial) without accruing clear advantages. To invoke public health measures simply because there are historical precedents would be the equivalent of using medications whose safety and efficacy have never been clearly demonstrated because individual clinicians are "convinced" they work.

Andrus and colleagues (5) thus have shed empirical light on an old debate. The authors conclude that as a result of three factors-that the period of infectiousness of syphilis is relatively long; that many persons reported multiple partners; and that those infected with the disease were likely to exchange sex for money or drugs-partner notification was unlikely to contribute significantly to the control of the epidemic. For example, among persons who reported exchanging sex for drugs or money (a major component of the epidemic), 92\% could not provide locating data for their partners. The conclusion that their paper reaches seems modest and clear: Partner notification must be supplemented by other public health interventions to control epidemic syphilis. The implications of their findings, however, are broader and touch on one of the most vigorously contested public policies regarding the control of sexually transmitted diseases and, especially, infection with the human immunodeficiency virus (HIV).

Recently, a vocal debate (6) has ensued whether the traditional control mechanisms for sexually transmitted diseases are effective for the control of HIV infection. Contact notification programs for syphilis and gonorrhea are now frequently cited as a potentially effective model for the control of HIV infection (79 ). It is critical that such applications be carefully reviewed: first, to assess the evidence that they make a 
difference for syphilis and gonorrhea control; and second, to evaluate the likelihood that they will help control HIV infection. Given the findings reported in this issue (5), there is reason to be cautious in applying the concept of partner notification for HIV infection. Indeed, controlling HIV infection presents problems that are common to other sexually transmitted diseases such as syphilis as well as significant barriers of its own.

State-mandated partner notification appears unlikely to effect positively the course of the HIV epidemic. Important social and cultural changes since the inception of contact tracing have compromised the efficacy of these programs. According to reports from the 1940 s, most index patients named only one contact. As sexual mores have changed, the increase in multiple and anonymous contacts has grown. Moreover, in the case of HIV infection, spread by both sexual contact and needle-sharing, the possibilities of truly effective notification become highly problematic. Considerable evidence exists that the actual number of contacts has increased at the same time that an index patient's ability to adequately identify his or her contacts has decreased (even presuming a cooperative index patient). The demands that this problem places on resources are, of course, considerable and must be measured against other potentially more effective interventions. Finally, the long period of infectiousness of HIV as well as the current inability to render persons noninfectious further diminishes the potential advantages of tracing contacts (10). It is important to recognize that the problem with partner notification in this instance is not that it violates civil liberties or that it is intrusive or stigmatizing (although these are important concerns), but the great uncertainty that it effectively serves the goals of public health and welfare.

Skepticism about partner notification programs as a means of controlling epidemic syphilis or HIV infection, of course, should not discount the significance of finding newly infected persons and assuring that they receive optimal treatment. In this respect, it is critical to distinguish the importance of warning ongoing sexual partners unaware of their risk of infection-and its implications-from legislatively mandated contact tracing programs (11). There is a compelling social interest to ensure that persons who may unknowingly be at ongoing risk for infection be told of the possibilities for testing and treatment.

Meeting social and ethical obligations to persons at risk should follow the basic ethical principles of clinical responsibility. Obviously, all persons found to be infected with HIV should be counseled and encouraged to identify ongoing contacts. They should be assisted by clinicians or public health officials to ensure that their contacts have the opportunity to be counseled and tested, and if infected, treated. Moreover, with the growing recognition of the possible benefits of early treatment among asymptomatic HIV-infected persons, the need to ensure that individuals at continuing risk be adequately warned is critical (12).
In framing public health policies, the emphasis must be on policies likely to be optimally inclusive, that draw individuals to the institutions of medicine and public health where desirable services, counseling, and treatment may be provided (13). Only policies broadly protective of the rights and privacy of infected persons are likely to achieve the public health goal of attracting at-risk individuals to be tested. Not to recognize the very particular properties of this epidemic will lead to policies which are unlikely to have a positive effect.

Those currently calling for comprehensive programs of partner notification have not adequately recognized the cultural meanings and significances of this epidemic. We must begin to set priorities in the development of social policies to meet the demands posed by the HIV epidemic. For example, to "find" new cases through partner notification only to discover that it is not possible to adequately meet the needs for counseling, treatment, social services, and care, places the cart before the horse. To ask persons to voluntarily name contacts when neither the index patient nor the partner are adequately protected from discrimination or assured of adequate services will lead to suspicion and justifiable skepticism among those at greatest risk.

No one would contest that the institutions of public health must reach out to those at risk for infection and assure that those infected receive optimal care and that those who are not infected change their behavior to reduce risk. What seems to be required is carefully targeted, voluntary, confidential notification of ongoing sexual partners of HIV-infected persons. Such programs may take various forms but the emphasis must be on out-reach and the provision of quality services.

Today, we are confronted by new shadows on the land, HIV infection and a resurgence of epidemic syphilis. The time has come, as Andrus and colleagues show, for a dispassionate evaluation of historic programs, programs that may have been effective under other circumstances, but in the contemporary context, fail to achieve their important goals.

\section{Allan M. Brandt, PhD \\ Harvard Medical School \\ Boston, MA 02115}

Requests for Reprints: Allan M. Brandt, PhD. Department of Social Medicine. Harvard Medical School, 25 Shattuck Street, Boston, MA 02115 .

Annals of Internal Medicine. 1990;112:481-483.

\section{References}

1. Parran T, Shadow on the Land: Syphilis. New York: Reynal \& Hilchcock; 1937.

2. Brandt AM. No Magic Bullet: A Social History of Venereal Disease in the United States Since 1880. New York: Oxford University Press; 1987.

3. Toomey KE, Cahill K, Blount JH, Havlak GR, Cates W Jr. AIDS politics and science [Letter]. N EngJ I Med. 1988;319:441-3.

4. Osborn JE. AIDS: politics and science. $N$ Engl $I$ Med. 1988;318:444-7.

5. Andrus JK, Fleming DW, Harger DR, et al. Partner notification: can it control epidemic syphilis? Am Intern Med. 1990;112:539-43.

6. Lambert $B$. In war on AlIS a tangle of rules about tracing, testing and telling. New York Times. 9 July 1989, E6. 
7. Toomey KE, Cates $\mathbf{W}$ Jr. Partner notification for the prevention of HIV infection. AIDS. 1989;3(Suppl 1):S57-S62.

8. Wykoff RF, Heath CW Jr, Hollis SL, et al. Contact tracing to identify human immunodeficiency virus infection in a rural commu. nity. JAMA. 1988;259:3563-6.

9. Potterat JJ, Spencer NE, Woodhouse DE, Muth JB. Partner notif cation in the control of human immunodeficiency virus infection. Am J Public Health. 1989;79:874-6.

10. Rutherford GW, Woo JM. Contact tracing and the control of human immunodeficiency virus infection. JAMA. 1988:259:3609-10.
11. Brennan TA. AIDS and the limits of confidentiality: the physicians duty to warn contacts of seropositive individuals. $J$ Gen Intern Med. 1989;4:242-6.

12. Levine C, Bayer R. The ethics of screening for early intervention in HIV disease. Am J Public Health. 1989;79:1661-7.

13. Francis DP, Anderson RE, Gorman ME, et al. Targeting AIDS prevention and treatment toward HIV-1-infected persons. The concept of early intervention. JAMA. 1989;262:2572-6.

(C) 1990 American College of Physicians 
Copyright of Annals of Internal Medicine is the property of American College of Physicians and its content may not be copied or emailed to multiple sites or posted to a listserv without the copyright holder's express written permission. However, users may print, download, or email articles for individual use. 